\title{
Study on Teaching of Higher Vocational Ideological and Political Course Based on Education Information Space
}

\author{
Zhaochu Qian \\ Chongqing Business Vocational College, Chongqing, 401331, China
}

Keywords: higher vocational colleges, information space, ideological and political course, study

\begin{abstract}
With the emergence of education information space, the originally dull learning becomes more colorful. Ideological and political course is a required course of college students, and is the main channel of ideological and political education for Chinese college students, and is related to healthy growth of young students. It is both important and urgent for higher vocational colleges to explore a way that is suitable for information space teaching of ideological and political course.
\end{abstract}

\section{Introduction}

In the $21^{\text {st }}$ century, with the continuous improvement of Chinese education information level, higher vocational colleges also accelerate construction of digital campus in order to promote constant enhancement of the level of higher vocational education information. The emergence of education information space enables learners to further get rid of restrictions of learning time and space, and makes relatively dull learning become more colorful. Ideological and political course is a required course of college students, and is the main channel of ideological and political education for Chinese college students. Strengthening and improving ideological and political education for college students are related to healthy growth of young students as well as the future and destiny of the country and nation. It is both important and urgent for higher vocational colleges to explore a way that is suitable for information space teaching of ideological and political course.

\section{Inevitability of higher vocational ideological and political course space teaching}

\section{(I) Inevitable trend of education information}

Undeniably, in this era of ubiquitous information, rapid development of modern computer information technology has profoundly changed production, living and learning styles of all people. The emergence of space teaching is a latest achievement of the development of modern computer information technology in terms of education. As early as the year of 2000, the Ministry of Education of PRC had clearly proposed in Notice on Implementing Network Course Construction Project in the New Century to: "construct about 200 basic network courses within approximately 2 years". Outline of National Plan for Medium and Long-term Education Reform and Development Program (2010-2020) issued on July 2010 explicitly pointed out to: "include education information into overall strategy of national information development, deploy education information network in advance, and promote modernization of educational content, teaching means and methods". Thus, strengthening reform and exploration of space teaching of higher vocational ideological and political theory course is not only the implementation of national strategy of developing education information, but also an inevitable trend of adapting to information development.

\section{(II) Inevitable way of ideological and political course teaching reform}

In the new era, the most primary and important task of higher vocational ideological and political course teaching is to help higher vocational students establish scientific world outlook, outlook on life and values, and insist on identification of socialist core value. According to provisions of Vocational Education Law of the People's Republic of China, higher vocational colleges bear historical responsibility of training senior applied talents for Chinese socialist construction. Higher vocational students have not only practical skills, but also good ideological and political consciousness and vocational spirit. With the rapid social development, quality-oriented education becomes the mainstream direction of educational development. Ideological and political course 
plays an important role in students' quality-oriented education, and shall be close to the reality of students, take students into full consideration, and have new ideas, in order to comprehensively improve qualities of higher vocational students and make them benefit from ideological and political course. Precisely, the proposal and practical teaching of education information space bring new direction for teaching reform of ideological and political course, and also promote gradual change of traditional ideological and political course teaching into space teaching.

\section{(III) Inevitable need of characteristics of higher vocational students}

In terms of source of students, current higher vocational students have practical problems, such as not very high overall qualities, obviously weak basic knowledge, uneven ideological status, poor learning ability and not sufficiently good behaviors etc. Meanwhile, in terms of age structure, current higher vocational students are of generations after the "1990s", and grow up in the context of economic globalization, cultural diversity and continuously deepening reform and opening up of China, and thus have self-confidence, openness, a strong sense of the times, distinct character and a strong sense of subject consciousness. However, they want freer and more diversified learning environment, and will not spare a glance for various forms and slogans. Through space teaching of ideological and political course, guide students to pay attention to the space of ideological and political course teachers when using the internet, while teachers shall try to use pictures, animation, videos and music etc when posting their own teaching resources, as college students after the "1990s" would love to hear and see and accept these forms, so as to increase students' concern and click rate of teachers' space and change higher vocational students' learning style from previous "required" to "require".

\section{Main features of higher vocational ideological and political course space teaching}

\section{(I) Teaching content advancing with the times}

As everyone knows, ideological and political course is closely combined with social status, and thus has very strong epochal character and timeliness and rapidly updating teaching content. Generally, in classroom teaching, teachers shall update case studies or audio and video etc constantly to enhance practical teaching effects. In traditional higher vocational ideological and political course teaching, teachers mostly use PPT to assist teaching in classroom, which has certain epochal character of teaching. However, with changes of the times, higher vocational students have aesthetic fatigue gradually towards simple PPT teaching, and thus teaching effects greatly decline. With the emergence of space teaching, ideological and political course teachers use space for teaching, post online videos related to ideological and political course on their own course resources through source code when publishing course resources, and take such videos as their own teaching content, and they could also prepare embedded tabular teaching plans, to include the most representative videos of their classes into teaching plans, and link such tabular teaching plans to online cases and news etc at any time. When teaching, students see the first-hand online materials without modification, which is more convincing. In this way, ideological and political course could have teaching content keeping up with social development and have greatly enhanced teaching timeliness.

\section{(II) Diverse personalities of teaching block}

In education information space, ideological and political course teachers could reconstruct courses or chapters to be taught in personal space, decompose teaching resources into concepts (meaning), principles, methods (skills), cases, pictures, videos (audios) and skill training etc, upload to space through the internet, form systematic and modular resource columns such as concept library, case library, method library, picture library, video library, and skill training library etc, break chapter distribution of textbooks, deconstruct course content, and reconstruct course system according to different modules. As a result, the entire teaching block has diverse personalities, which are very attractive to students. In addition, ideological and political course teachers use hyperlink technology to prepare tabular electronic teaching plans, through which students could clearly know the main content, keys and difficulties etc of this course, as if teachers are giving lessons in virtual multimedia classrooms and students are looking up information resources in 
virtual libraries, so that ideological and political course has more vivid teaching and independent and funny learning.

\section{(III) Multidimensional and interactive teaching methods}

Traditional ideological and political course teaching method is quite simple in higher vocational colleges, and one teacher shall teach dozens of or even hundreds of students and have one-way exchanges, and mainly have teachers' questioning \& students' answering or teachers' setting of a certain topic \& students' discussion and exchanges. Besides, the main teaching carrier is classroom, and students can hardly communicate with teachers after classes. In space, communication forms include message, private letter, group discussion, teachers' comments of students' assignment, and students' questions after browsing teachers' course resources etc. Extensive communication and discussion can be carried out among students, and thus ideological and political course teaching realizes change from traditional one-way communication to two-way interaction, changes teachers' teaching and students' listening in traditional teaching method, realizes students' independent learning, collaborative learning and sharing learning, makes ideological and political course no longer boring and dull, and enhances teaching effects of ideological and political course.

\section{(IV) Teamwork in teaching resources}

For a long time, sharing of college teaching resources has been a great problem that colleges have been devoted to solving but fail. In particular, it is more difficult to share ideological and political course resources effectively because of rapid update and strongly timely content. Education information space is an open platform, which realizes mutual exchanges between inside and outside colleges, among teachers, between teachers and students, and among students. Space even provides students' division of labor among colleges, majors and grades for teaching activities, so that they could discuss jointly about problems and difficulties through large space platform and work together to obtain optimal solutions. Such resource co-construction and sharing method not only solves problems of ideological and political course teaching resources like not timely update and lack of resources, but also enriches three-dimensional resources of ideological and political course teaching and realizes teamwork in teaching resources.

\section{Problems in higher vocational ideological and political course space teaching practice}

\section{(I) Lack of monitoring of students' learning}

As mentioned above, with characteristics of source of higher vocational students, students have poor learning habits, and some have weak self-control ability, and thus have poor learning consciousness, while education information space is "individualized" teaching and highly depends on students' learning consciousness. In particular, in higher vocational colleges, students generally pay more attention to specialized courses while less to public courses and attach inadequate importance to ideological and political course under the influence of traditional concepts. They may learn carelessly or even do not learn once there is a lack of real-time face-to-face monitoring of teachers. Meanwhile, as space teaching is a new thing, evaluation of students shall be further standardized apparently compared with traditional evaluation methods, and it is difficult to conduct quantitative evaluation of students' learning effects and quality in space according to an objective standard.

\section{(II) Problem in construction of teachers}

As education information space has a short history, teaching concepts and ability of some ideological and political course teachers in higher vocational colleges cannot adapt to actual requirements of space teaching, and are far from enough in terms of new teaching space models and new methods, and teaching space construction has inadequately appropriate overall layout and column setting. Besides, space fails to highlight its professional features, is even inferior to overall level of students' space, has simple interactive form and cannot integrate information resources effectively. Apparently, to improve space teaching effects of ideological and political course, it is imperative to strengthen training for ideological and political course teachers.

(III) Difficulty in effective resource screening

There are abundant learning resources for education information space teaching, and generally 
one course has different versions of teaching resources in space. It is difficult for higher vocational students, who have weak information screening ability, to screen effective learning resources. Meanwhile, ideological and political course has strict requirements in terms of stringency and science of teaching content, and misguidance may be resulted in easily once some resources are inconsistent with policies and orientation as higher vocational students lack rational distinguishing ability. Therefore, it is very urgent to screen effectively in space teaching of ideological and political course.

\section{(IV) Need of further in-depth teaching research}

As education information space is an integrated service platform, there are many researches on its generality, and such researches mainly focus on important disciplines and less on public courses. Thus, there is a lack of systematic and comprehensive study on space teaching law of ideological and political course. Compared with other specialized courses, disciplinary characteristics of ideological and political course are insufficiently studied, space resource collection methods have no innovation, there is a lack of effective and characterized resources that can attract students, and teaching methods are sometimes only simple decomposition of PPT courseware. Therefore, the need of researches on space teaching of ideological and political course shall be highly concerned.

Space teaching of ideological and political course is a teaching reform for traditional ideological and political teaching. It has space as a platform, changes the awkward situation that network is merely auxiliary means of classroom teaching under traditional mode, and improves effects of moral education. However, due to short history of ideological and political course space teaching since its emergence and particularly such teaching is at the exploration and practice stage in higher vocational colleges, although it achieves good teaching effects and accumulates certain precious experience after efforts, there are a series of problems, which require peers and researchers of ideological and political course to strengthen practice and summary constantly, improve space teaching level of higher vocational ideological and political course constantly, and promote training quality of higher vocational talents.

\section{Acknowledgments}

This paper is one of phased achievements of 2013 Chongqing Education Scientific Planning Project "Study on Promoting Higher Vocational Education Teaching Mode with the Core of Education Information Space Teaching” (Project Approval No.: 2013-ZJ-063, host: He Hongmei).

\section{References:}

1. Zhu Wei, On Excellent Construction of Teaching Space of Ideological and Political Theory Course under the Education Information Background [J]. Moral Education Online, 2013 (10).

2. Tang Zhaoyun et al. Reform and Exploration of Space Teaching of Higher Vocational Ideological and Political Theory Course Based on Cloud Platform [J]. Journal of Hunan University of Science and Technology, 2014 (2).

3. Li Xiujuan et al. Analysis of Motivation Mechanism of Change of Traditional Ideological and Political Teaching to Ideological and Political Space Teaching [J]. Journal of Changsha Social Work College, 2012 (2).

4. Lin Haichun. Study on College Network Ideological and Political Educational Methods Based on World University City Platform [J]. China Education Information, 2012 (2). 